\title{
INDICATORS FOR FOSTERING ENVIRONMENTAL SUSTAINABILITY IN THE CONTEXT OF RESPONSIBLE RESEARCH AND INNOVATION.
}

\author{
Tomás Gómez-Navarro ${ }^{1}$, Iván Ligardo-Herrera ${ }^{1}$, Wilson Jácome-Enríquez ${ }^{2}$, \\ ${ }^{1}$ Institute of Energy Engineering IIE, Universitat Politècnica de València, Valencia 46022, \\ Spain; \\ 2 Construction and Earth Sciences Department, Universidad de las Fuerzas Armadas - \\ ESPE. Avenida General Rumiñahui s/n, Sangolquí, Ecuador
}

\begin{abstract}
In this paper we suggest a methodology for identifying, selecting and prioritizing indicators for fostering the environmental sustainability of research projects. Our research is integrated in the framework of Responsible Research and Innovation. The methodology is based on the AHP method, the environmental indictor of the Global Reporting Initiative, and the interview to science management experts and environmental assessment experts. It has been applied to information and communication technology research projects.

The procedure has proven to be feasible and satisfactory. The starting list of 34 indicators was reduced to 19 in an AHP model of three levels: RRI dimensions, environmental aspects and environmental indicators. Applying the Pareto analysis, 4 environmental indicators add more than $80 \%$ of the total weight and we suggest to choose them, discarding the others. That way, research teams or policy makers can focus on the most important indicators for fostering the environmental sustainability of the selected research discipline.
\end{abstract}

Keywords: AHP, RRI, Environmental indicators, Sustainability.

\section{Introduction}

Anthropogenic environmental impacts (EI) are on top of the more global and urgent threats humankind is responsible for. Research and innovation have a great potential to change that situation, contributing the environmental sustainability of development. In fact, throughout Europe, one the most dominant public debates about to the role of science in society have revolved lately around environmental impacts and sustainability.

With the intention of fostering responsible research, the European Commission (EC) has been promoting a cross-cutting issue named "Responsible Research and Innovation (RRI)". The most widely used definition of RRI could be the one given by von Schomberg (von Schomberg 2011): "(RRI) is a transparent, interactive process by which societal actors and innovators become mutually responsive to each other with a view to the (ethical) acceptability, sustainability and societal desirability of the innovation process and its marketable products". The ultimate aim is to allow a proper embedding of scientific and technological advances in our society. 
Several works under the auspices of the EC have found that RRI involves six key areas for the dialogue with stakeholders (Strand et al. 2015) i) Public Engagement, ii) Gender Equality, iii) Science education, iv) Open Access, v) Ethics and vi) Governance. And lately two more areas were added: Sustainability (environmental) and Social Justice.

For the six former key areas of RRI, guidance for indicators have also been provided. In the work referred to the authors put forward a framework for the indicators with two dimensions: Perception and Performance, the latter further divided into Process and Outcomes. Then, indicators are suggested for the six key areas and the two dimensions (Monsonís-Payá et al. 2017; Strand et al. 2015).

Unfortunately, for the purpose of our research, the framework is neither applied nor are indicators suggested for the added areas of Social Justice and Sustainability. There is one exception though, the work of (Kettner et al. 2014) suggesting that indicators for the area of sustainability in RRI should aim at:

- Monitoring stocks (renewable and non-renewable resources);

- Monitoring flows (consumption and regeneration of stocks);

- Mapping and monitoring stock-flow interactions;

- Mapping fund elements (labour and technology) and how they influence the stockflow interactions;

- Monitoring ecosystem services and their effect on human well-being.

However, that proposal is not practical for the management of research activities. Hence, In this paper we aim to put forward a methodology for identifying, prioritizing and proposing environmental sustainability indicators for RRI practitioners based on the method AHP. Those indicators are intended to integrate and monitor during the research the potential environmental impacts of the process, its outcomes and its perception. For the implementation of the methodology we have selected Information and Communication Technology projects (ICT). The reason for that is those projects normally are not considered to have relevant environmental responsibilities and, thus, they do not normally address environmental impacts within their targets.

\section{Literature Review}

The search for publications of RRI (or Corporate Social Responsibility) addressing environmental sustainability, gave a series of tools and some general recommendations. About the tools, the most relevant are listed in table 1.

Table 1. Main tools for fostering environmental sustainability

\begin{tabular}{c|l}
\hline \multicolumn{1}{c}{ RRI tools } & \multicolumn{2}{c}{ Use for fostering environmental sustainability } \\
\hline $\begin{array}{c}\text { Ecodesign / } \\
\text { Eco- } \\
\text { innovation }\end{array}$ & $\begin{array}{l}\text { Eco-innovation is the incorporation of sustainability throughout all R\&I } \\
\text { business activities. It is based on life cycle thinking and it entails a coordinated } \\
\text { set of modifications or novel solutions to products, processes, market approach } \\
\text { and organizational structure. }\end{array}$ \\
\hline $\begin{array}{c}\text { ISO 26000 } \\
\text { standard }\end{array}$ & $\begin{array}{l}\text { ISO 26000 provides guidance on how organizations can operate in a } \\
\text { responsible way. }\end{array}$ \\
\hline $\begin{array}{c}\text { Global } \\
\text { Reporting } \\
\text { Initiative } \\
\text { (GRI) }\end{array}$ & $\begin{array}{l}\text { Standards on sustainability reporting and disclosure. Its database could be a } \\
\text { good catalogue of examples as it has over 25,000 reports from more than } \\
10,000 \text { organizations of more than 90 countries. It suggests around 30 different } \\
\text { indicators for measuring environmental aspects, including climate change }\end{array}$ \\
\hline
\end{tabular}




\begin{tabular}{c|l}
\hline & $\begin{array}{l}\text { (GRI 2013). There are sector supplements but, although there is one about } \\
\text { public agency, none specifically covers research and innovation. }\end{array}$ \\
\hline $\begin{array}{c}\text { AA1000 } \\
\text { standards }\end{array}$ & $\begin{array}{l}\text { Framework for organizations to apply the principles of Accountability along } \\
\text { with sustainability assurance and stakeholder management. }\end{array}$ \\
\hline \multirow{2}{\text{UNGlobal}}{$\begin{array}{l}\text { Compact } \\
\text { their strategies and operations with 10 Principles on Human Rights, Labour, } \\
\text { Environment and Anti-corruption; and take strategic actions to advance } \\
\text { broader societal goals, such as the UN Sustainable Development Goals, with } \\
\text { an emphasis on collaboration and innovation. }\end{array}$} \\
\hline
\end{tabular}

In conclusion, we have selected the Global Reporting Initiative as the reference for the environmental indicators.

\section{Research Design/Methodology}

For the selection and assessment of the indicator to foster sustainability, two experts were recruited. They are experienced researchers one of the discipline of environmental assessment and another of the discipline of science management. They conducted all the activities, made all the comparisons and decisions of the methodology (see figure 1.).

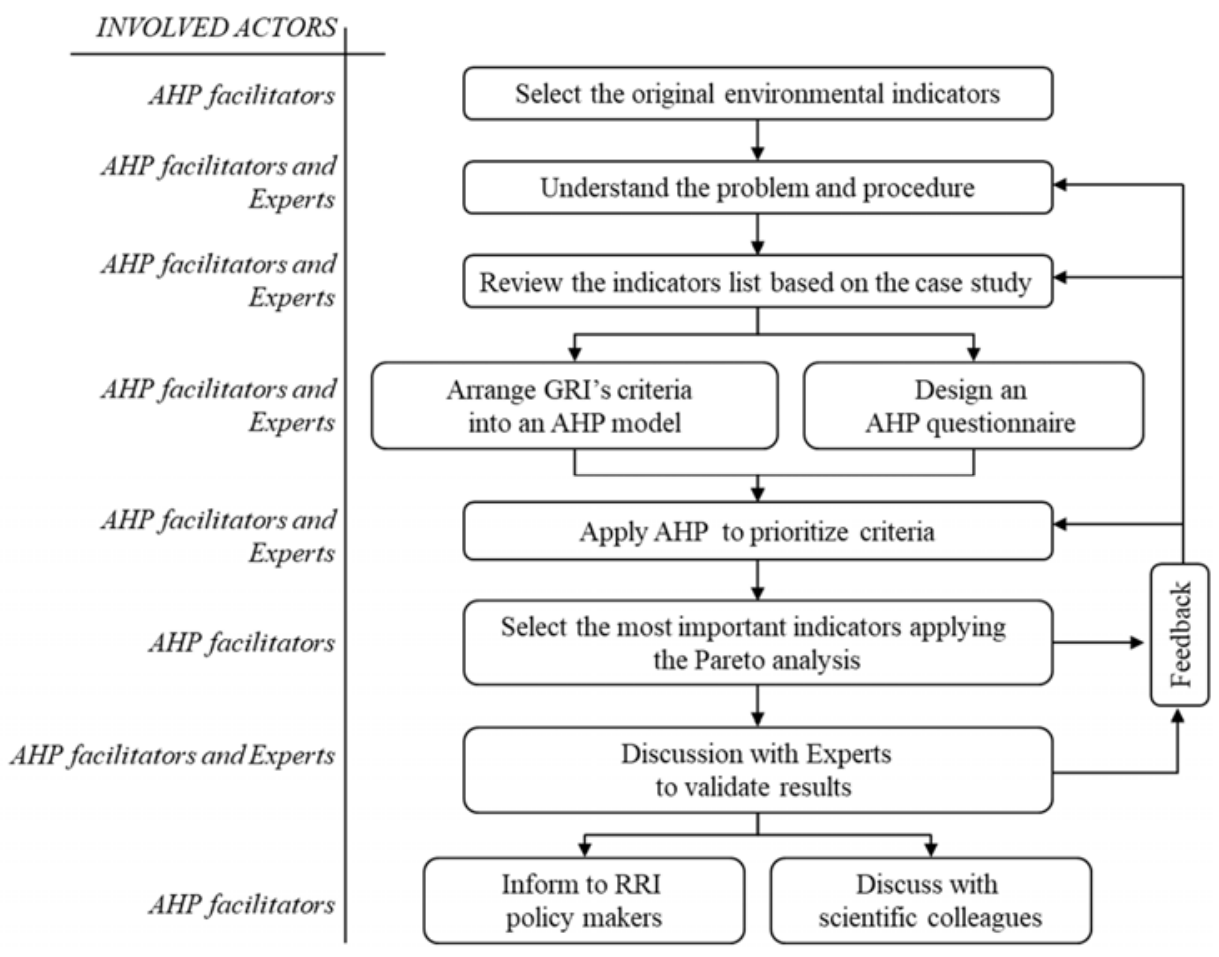

Figure 1. Proposed methodology

Table 2 shows the environmental indicators selected. They are a simplification from the ones GRI proposes based on the experience of the experts, for a complete list see (GRI 2013).

Once the criteria determined, and related to research in the realm of information and communication technology, pairwise comparison was conducted to assess the relative importance of criteria first (indicators) and clusters then (aspects and RRI dimensions). 
Reviews were performed whenever the inconsistency ratio was higher than 0,1 . In the following section we discuss our findings.

Table 2. Selected GRI Environmental indicators

\begin{tabular}{|c|c|c|}
\hline RRI & Aspect & Indicator \\
\hline \multirow{5}{*}{ PROCESS } & MATERIALS & $\begin{array}{l}\text { G4-EN1. Materials used by weight or volume } \\
\text { G4-EN2. Percentage of materials used that are recycled input } \\
\text { materials }\end{array}$ \\
\hline & ENERGY & $\begin{array}{l}\text { G4-EN3. Energy consumption within the organization } \\
\text { G4-EN5. Energy intensity } \\
\text { G4-EN7. Reductions in energy requirements of products and } \\
\text { services }\end{array}$ \\
\hline & WATER & $\begin{array}{l}\text { G4-EN8. Total water withdrawal by source } \\
\text { G4-EN10. Percentage and total volume of water recycled and } \\
\text { reused }\end{array}$ \\
\hline & EMISSIONS & $\begin{array}{l}\text { G4-EN15. Direct greenhouse gas (GHG) emissions } \\
\text { G4-EN16/17. Indirect greenhouse gas (GHG) emissions } \\
\text { G4-EN20. Emissions of ozone-depleting substances (ODS) } \\
\text { G4-EN21. NOx, SOx, and other significant air emissions }\end{array}$ \\
\hline & $\begin{array}{l}\text { EFFLUENTS AND } \\
\text { WASTE }\end{array}$ & $\begin{array}{l}\text { G4-EN22. Total water discharge by quality and destination } \\
\text { G4-EN23. Total weight of waste by type and disposal method } \\
\text { G4-EN25. Weight of transported, imported, exported, or } \\
\text { treated waste deemed hazardous under the terms of the Basel } \\
\text { Convention2 Annex I, II, III, and VIII, and percentage of } \\
\text { transported waste shipped internationally }\end{array}$ \\
\hline \multirow{4}{*}{ OUTCOMES } & $\begin{array}{l}\text { PRODUCTS AND } \\
\text { SERVICES }\end{array}$ & $\begin{array}{l}\text { G4-EN27. Extent of impact mitigation of environmental } \\
\text { impacts of products and services }\end{array}$ \\
\hline & TRANSPORT & $\begin{array}{l}\text { G4-EN30. Significant environmental impacts of transporting } \\
\text { products and other goods and materials for the organization's } \\
\text { operations, and transporting members of the workforce }\end{array}$ \\
\hline & OVERALL & $\begin{array}{l}\text { G4-EN31. Total environmental protection expenditures and } \\
\text { investments by type }\end{array}$ \\
\hline & $\begin{array}{l}\text { SUPPLIER } \\
\text { ENVIRONMENTAL } \\
\text { ASSESSMENT }\end{array}$ & $\begin{array}{l}\text { G4-EN33. Significant actual and potential negative } \\
\text { environmental impacts in the supply chain and actions taken }\end{array}$ \\
\hline PERCEPTION & $\begin{array}{l}\text { ENVIRONMENTAL } \\
\text { GRIEVANCE } \\
\text { MECHANISMS }\end{array}$ & $\begin{array}{l}\text { G4-EN34. Number of grievances about environmental } \\
\text { impacts filed, addressed, and resolved through formal } \\
\text { grievance mechanisms }\end{array}$ \\
\hline
\end{tabular}

\section{Data/Model Analysis}

Figures 2 shows the relative weight of each element of the AHP model, while the figure 3 shows the final weights of the selected GRI indicators.

As can be seen in the pictures, the more important cluster was OUTCOMES, followed by PERCEPTION and PROCESS. Among the GRI environmental aspects, PRODUCTS AND SERVICES, within OUTCOMES, has a total weight of 0,365 . Followed by ENVIRONMENTAL GRIEVANCE MECHANISMS, within PERCEPTION, with a total weight of 0,260 . Finally, among indicators, G4-EN27 has a total weight of 0,365, G4-EN34 a weight of 0,260 and G4-EN has a weight of 0,154 . 


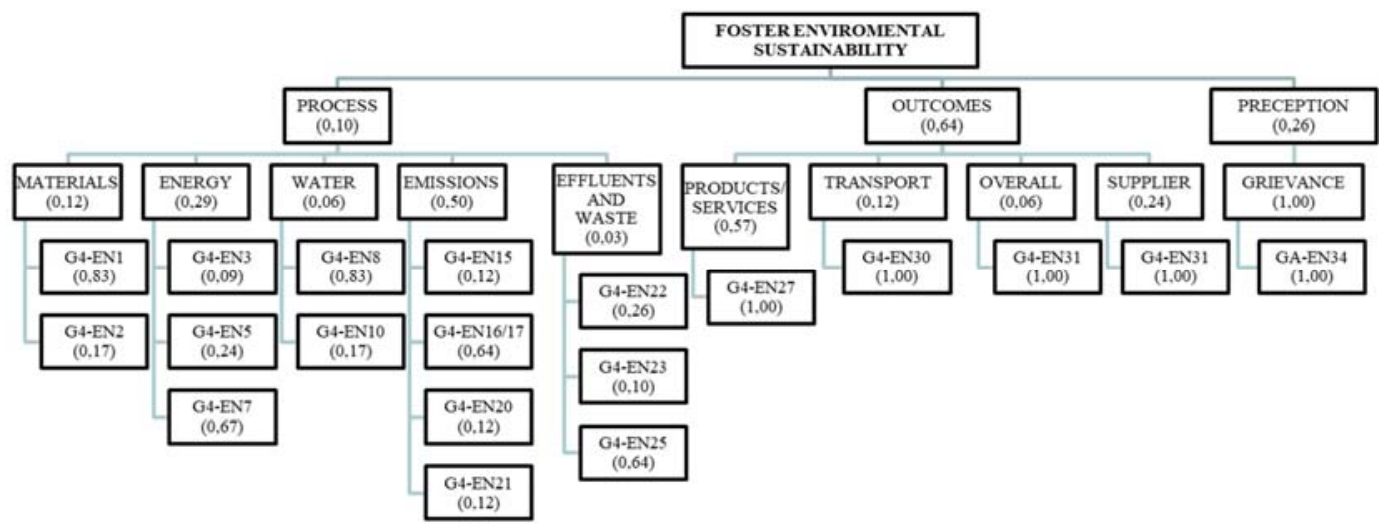

Figure 2. Relative weights of all the elements.

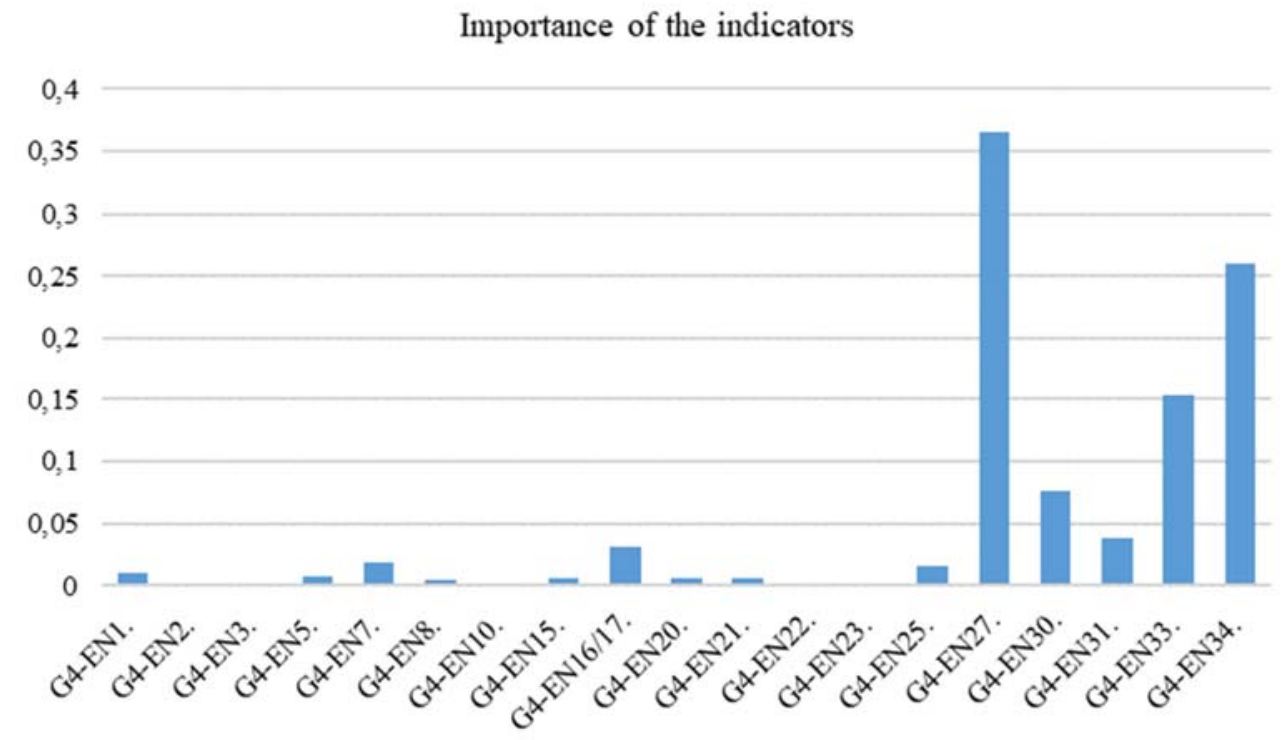

Figure 3. Final weights of the selected GRI indicators for the case of ICT research projects.

Applying the Pareto analysis, the set of indicators that add more than $80 \%$ of the final weights are those listed below. Therefore, the researchers, or the policy makers involved in ICT investigation projects, should focus on those indicators for fostering their environmental sustainability.

- G4-EN27. Extent of impact mitigation of environmental impacts of products and services

- G4-EN30. Significant environmental impacts of transporting products and other goods and materials for the organization's operations, and transporting members of the workforce

- G4-EN33. Significant actual and potential negative environmental impacts in the supply chain and actions taken

- G4-EN34. Number of grievances about environmental impacts filed, addressed, and resolved through formal grievance mechanisms 


\section{Conclusions}

In this paper we suggest a methodology for identifying, selecting and prioritizing indicators for fostering the environmental sustainability of research projects. The research is integrated in the framework of Responsible Research and Innovation. It is based on the AHP method and has been applied to information and communication technology research projects.

The literature review has shown sustainability is getting ever more attention from RRI researchers and practitioners, although it was not included from the beginning in the six dimensions of RRI. Therefore, very few specific proposals of RRI on sustainability could be acknowledged. Based on the global Reporting Initiative proposal we have selected a set of environmental indicators to address and manage the environmental impacts of ICT research projects.

Finally, it is important to recall our purpose is not so much normative as descriptive. We acknowledge our review may have taken no notice of some important publications or projects. Besides, our review relies on what experts judge more or less important for sustainability. Therefore, we are presenting a methodology more than a framework for assessing the environmental sustainability of ICT research initiatives.

Acknowledgments: This research has been funded by the Spanish Agencia Estatal de Investigación within the project Propuesta de Indicadores para Impulsar el Diseño de Una Política Orientada al Desarrollo de Investigación e Innovación Responsable en España. INPERRI. (CSO2016-76828-R). Also, the authors would like to thank the "Bolívar Gana con Ciencia" project from the Gobernación de Bolívar (Colombia).

\section{Key References}

GRI, 2013. G4 Sustainability Reporting Guidelines - Part 1: Reporting Principles and Standard Disclosures, Available at: www.globalreporting.org.

Kettner, C., Köppl, A. \& Stagl, S., 2014. Towards an operational measurement of socioecological performance. WIFO Working Paper no 52, Available at: http://www.wifo.ac.at/.

Monsonís-Payá, I., García-Melón, M. \& Lozano, J.-F., 2017. Indicators for Responsible Research and Innovation: A Methodological Proposal for Context-Based Weighting. Sustainability, 9(12), p.2168. Available at: http://www.mdpi.com/20711050/9/12/2168.

von Schomberg, R., 2011. Prospects for Technology Assessment in a framework of responsible research and innovation. Technikfolgen abschätzen lehren: Bildungspotenziale transdisziplinärer Methoden, pp.39-61. Available at: http://www.farinn.eu/pdf/prospects-for-technology-assessment-in-a-framework-ofresponsible-research-and-innovation.pdf.

Strand, R. et al., 2015. Indicators for promoting and monitoring Responsible Research and Innovation Report from the Expert Group on Policy Indicators, 